Article

\title{
Assessing Ecological Carrying Capacity in the Guangdong-Hong Kong-Macao Greater Bay Area Based on a Three-Dimensional Ecological Footprint Model
}

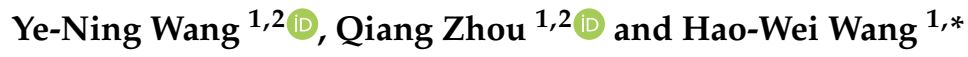 \\ 1 Key Laboratory of Urban Environment and Health, Institute of Urban Environment, \\ Chinese Academy of Sciences, Xiamen 361021, China; wangyening13@mails.ucas.ac.cn (Y.-N.W.); \\ qzhou@iue.ac.cn (Q.Z.) \\ 2 University of Chinese Academy of Sciences, Beijing 100049, China \\ * Correspondence: hwwang@iue.ac.cn
}

Received: 30 September 2020; Accepted: 18 November 2020; Published: 20 November 2020

\begin{abstract}
As one of the most developed and competitive metropolitan areas in the world, the contradiction between resource depletion and sustainable development in the Guangdong-Hong Kong-Macao Greater Bay Area (GHMGBA) has become a crucial issue nowadays. This paper analyzed the natural capital utilization patterns in GHMGBA during 2009-2016 based on a three-dimensional ecological footprint model. Ecological carrying capacity intensity $\left(\mathrm{EC}_{\text {intensity }}\right)$ was calculated to optimize the accounting of ecological carrying capacity (EC). Ecological footprint depth $\left(\mathrm{EF}_{\mathrm{depth}}\right)$ and $\mathrm{EC}_{\text {intensity }}$ were quantitatively investigated and influencing factors were further explored based on a partial least squares (PLS) model. Results showed that GHMGBA had been operating in a deficit state due to the shortage of natural capital flow and accumulated stock depletion. The highest $\mathrm{EF}_{\text {depth }}$ occurred in Macao (17.11 26.21) and Zhongshan registering the lowest (2.42 3.58). Cropland, fossil energy and construction land constituted the most to total ecological deficit, while woodland was continuously in a slight surplus. Natural capital utilization patterns of 11 cities were divided into four categories through hierarchical clustering analysis. Driving factors of $\mathrm{EF}_{\mathrm{depth}}, \mathrm{EC}_{\text {intensity }}$ and three-dimensional ecological deficit $\left(\mathrm{ED}_{3 \mathrm{D}}\right)$ were mainly students in primary and secondary education, disposable income, consumption expenditure, $R \& D$ personnel and freight volume. Our findings could provide guidance for decision-makers to develop resource utilization portfolios in GHMGBA.
\end{abstract}

Keywords: ecological footprint size; ecological footprint depth; ecological carrying capacity intensity; driving factor; GHMGBA

\section{Introduction}

Natural capital is the stock of natural ecosystems that yields a flow of valuable ecosystem goods or services to meet human needs. The productive land/water in the ecological footprint theory can be an iconic metric to represent natural capital and its capital flow [1,2]. Therefore, ecological footprint (EF) model has been applied across various spatial scales by the government and academia to assess regional sustainable development [3-6]. The dynamic study of ecological footprint and carrying capacity is conducive to optimizing the industrial structure and constructing the ecological compensation system and that has a crucial theoretical and practical significance for realizing sustainable development within social-economic-natural complex ecosystems.

Borucke et al. [7] calculated the natural capital footprint of more than 200 countries and their results showed that most regions were in a state of ecological deficit (ED). Researchers have also found 
that most provinces of China were in deficit with serious trends in past decades [8]. Yue et al. [9] studied the spatial distribution pattern of ecological carrying capacity (EC) using high-resolution image data and emphasized its spatial heterogeneity. EC calculated by the emergy model was more conservative than the EF model [10], and ecological and economic systems were significantly spatially uncoordinated [11]. Ecological footprint size $\left(\mathrm{EF}_{\text {size }}\right)$ and ecological footprint depth $\left(\mathrm{EF}_{\text {depth }}\right)$ were introduced into the three-dimensional ecological footprint (3DEF) model by Niccolucci et al. [12,13] to transparently distinguish between natural capital flows and stocks. Fang et al. $[14,15]$ extended the 3DEF model to China and made optimizations to solve the mutual offset problem within different lands. The appropriation rate of capital flows and use ratio of stocks to flows were introduced to represent the natural capital use in a case study. Peng et al. [16] conducted a multidimensional "ecology-equity-efficiency" framework integrated with the Gini coefficient of $\mathrm{EF}_{\text {size }}$ and variation coefficient of $\mathrm{EF}_{\text {depth }}$ to characterize the equality of capital flow and stock occupations. All 13 cities in the Beijing-Tianjin-Hebei urban agglomeration showed a deficit state and $\mathrm{EF}_{\text {depth }}$ was influenced by the amount and structure of consumed resources [17]. Natural capital flow and stock utilization and their heterogeneity within different lands in other regions were analyzed and estimated coupled with various prediction models [18-20].

The 3DEF model was proved to be more effective for depicting resource utilization, and bidirectional impacts between economic development and energy consumption were revealed [21,22]. Constructing models with the population, affluence, policies and technical level of a region could describe the impact of economic and social driving factors on environmental pressure [23-25]. Sun [26] proposed a complete decomposition analysis method and explained the driving factors of the energy EF. Al-Mulali [27] confirmed that GDP, non-renewable energy consumption, and urbanization could increase $\mathrm{CO}_{2}$ emission while renewable energy consumption, trade openness, and energy prices reduce it in 27 advanced economies. Based on partial least square (PLS) model, Zhang and Zeng [28] found that the population size and social economy were the main influencing factors of the dynamic changes in capital utilization of the Pearl River Delta urban agglomeration. Andersson and Lindroth [29] explored the transfer path of EF between developed and less developed countries, revealing the ecological unfairness in international trade. Economic and financial development sparked off nature capital consumption while contradictory results were also found on globalization [30,31]. An environmental Kuznets curve hypothesis based on EF measurements was demosntrated in low income, middle income and high-income group countries [32]. The innovation activity and economic freedom would have a major impact on the variability of EF [29,33,34]. Socio-demographic variables such as urbanization, education, technology, life expectancy could improve the environment positively in the long term, especially in undeveloped countries [32,35-37]. However, the actual EC cannot be measured without the particular original year especially when accounting for human subjective initiative [38,39]. This confuses the resource exhaustion threshold within the planetary boundaries [40]. It was more accurate to calculate the equilibrium factor and yield factors based on local conditions [41]. Compared with the economic level and resident lifestyle, the level of biomass use per capita was more subjected to land use patterns and population density in the specific region [42].

As the leading area for economic reform and opening up in China, the Guangdong-Hong Kong-Macao Greater Bay Area (GHMGBA) has become one of the regions with the largest population, the strongest economic vitality and the highest level of social development in the world. However, such economic prosperity has been coupled with environmental degradation especially in recent decades. Thus, it is imperative to assess the natural resource requirements for local sustainable development. Identify natural capital utilization is the core issue to build GHMGBA into a living paradise with limited resources. There were few studies of EF accounting in the case of GHMGBA involving Hong Kong and Macao with the "one country, two systems" policy. This paper aims to present a thorough tool for assessing natural capital utilization at municipal scale with 3DEF model. The equivalence and yield factors of 11 cities were calculated based on output biomass data during 2009-2016 to improve research's credibility. $\mathrm{EF}_{\text {size }}$ and $\mathrm{EF}_{\text {depth }}$ were calculated and temporal-spatial 
characteristics of different land types were described. Ecological carrying capacity intensity ( $\left.\mathrm{EC}_{\text {intensity }}\right)$ was constructed to represent the potential carrying capacity of social capital. The driving factors of $\mathrm{EF}_{\text {depth }}, \mathrm{EC}_{\text {intensity }}$ and ED were further explored with PLS regression analysis. The results could provide basic data support for industrial structure adjustment and ecological redline policy for regional development planning and management.

\section{Study Area}

The Guangdong-Hong Kong-Macao Greater Bay Area (GHMGBA) comprises the two Special Administrative Regions (SAR) of Hong Kong and Macao, and the nine municipalities of Guangzhou, Shenzhen, Zhuhai, Foshan, Huizhou, Dongguan, Zhongshan, Jiangmen and Zhaoqing in Guangdong Province, China (Figure 1). Dominated by subtropical and tropical monsoon climates, average annual rainfall in GHMGBA is $1300-2500 \mathrm{~mm}$ and the average temperature is $22.3^{\circ} \mathrm{C}$. The entire territory area is $56,000 \mathrm{~km}^{2}$ with a total population of about 68 million. Her total economic size and population of 9 cities in the Pearl River Delta (PRD) account for $85 \%$ and 52\% of Guangzhou Province, respectively. And the 11 cities in GHMGBA account for 13\% of the country's overall GDP in 2016. As the specific region with different systems and economic mechanisms, her development is accorded the status of key strategic planning in China, weighing great significance in the country's implementation of innovation-driven development and commitment to reform and opening-up. The objectives are to further deepen cooperation amongst Guangdong, Hong Kong and Macao, fully leverage composite advantages of the three regions to develop an international first-class bay area ideal for living, working and traveling.

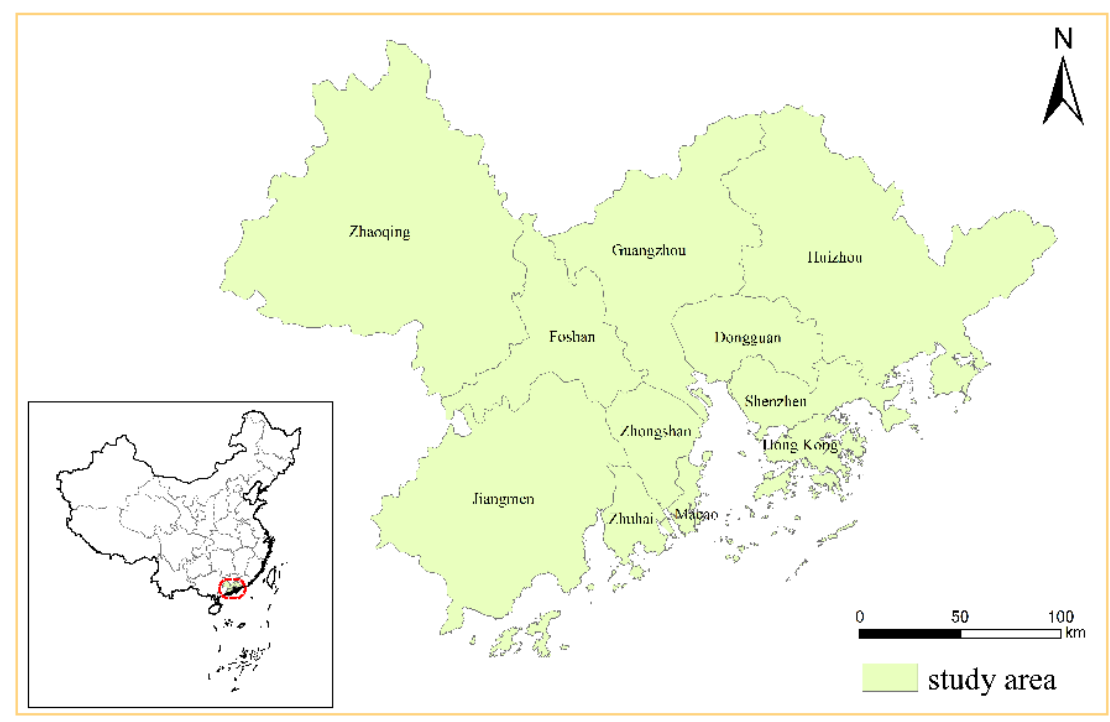

Figure 1. Location of the study area.

\section{Materials and Methods}

\subsection{Materials}

According to the conventional EF model [2], all items were classified into six types: cropland, grassland, woodland, water area, fossil energy land and construction land. This research used primary data extracted from Statistical Yearbooks of 11 cities in GHMGBA, Agrotechnical Economics Manual (Revised), Food and Agriculture Organization of the United Nations, and the study period was set as 2009-2016. The data herein collected for calculating EF and EC included biological production and energy consumption. Biomass production rather than consumption was gathered to effectively elucidate the local land pressure. Thus, the interregional import and export adjustment amounts would be not considered in this research. No matter whether it is produced locally or not, fossil 
energy and electricity are consumed by GHMGBA create ecological pressure for Fossil energy and Construction land, respectively. There is no central heating in GHMGBA, so the thermal energy is not considered (Table 1). Meanwhile, global average product data in 2009-2016 extracted from the Food and Agriculture Organization of the United Nations were used as references to conveniently compare with other regions, and energy consumption EF was converted with the average calorific values of various items [43]. Based on the integrity and accessibility of data, the yearly patent data, scientific and technological activities' personnel and research funding were extracted from the Statistical Yearbooks of 11 cities. Guangdong province's data in each year were taken as a benchmark to calculate $\mathrm{EC}_{\text {intensity }}$ to be conducive to model uniformity.

Table 1. Biological and energy resource data selected for 3DEF model in Guangdong-Hong Kong-Macao Greater Bay Area (GHMGBA).

\begin{tabular}{rc}
\hline Biological Products/Energy Consumption Items & Land Categories \\
\hline Cereals, tubers, beans, oil-bearing crops, vegetables, pork, poultry eggs & Cropland \\
Beef, mutton, milk, sheep wool, goat wool, cashmere & Grassland \\
Honey, tea, wood, fruit & Woodland \\
Fish, shrimps, prawns and crabs, shellfish, algae & Water area \\
Coal, coke, crude oil, gasoline, kerosene, diesel oil, fuel oil, natural gas & Fossil energy land \\
Electricity & Construction land \\
\hline
\end{tabular}

Land use data of nine cities in Guangdong were derived from the Land Survey Results Sharing Application Service Platform (http://tddc.mlr.gov.cn/to_Login). Hong Kong and Macao's land use data were taken from the yearbooks and $10 \mathrm{~m}$ resolution global land cover data [44]. These data were arranged with the connotations of EF and current land use classification. The factors influencing ecological footprint and carrying capacity are complex and heterogeneous in various regions. Based on previous studies $[16,28,45,46]$, accounting for the principles of data integrity, availability and comparability, 20 indicators were selected from yearbooks to comprehensively reflect the social development status of GHMGBA, as shown in Table 2.

Table 2. Driving factors of ecological footprint depth $\left(\mathrm{EF}_{\text {depth }}\right)$, ecological carrying capacity intensity $\left(\mathrm{EC}_{\text {intensity }}\right)$ and per capita three-dimensional ecological deficit $\left(\mathrm{ED}_{3 \mathrm{D}}\right)$ in GHMGBA.

\begin{tabular}{|c|c|c|}
\hline Dimension of Index & Driving Factors & Unit \\
\hline Population & Permanent population & 10,000 persons \\
\hline & GDP of the primary industry & \\
\hline Economics & $\begin{array}{c}\text { GDP of the secondary industry } \\
\text { GDP of the tertiary industry } \\
\text { GDP }\end{array}$ & 100 million RMB \\
\hline Foreign trade & Total value of exports & 10,000 dollars \\
\hline Policy & $\begin{array}{l}\text { total fixed capital } \\
\text { total retail sales }\end{array}$ & $\begin{array}{l}100 \text { million RMB } \\
100 \text { million RMB }\end{array}$ \\
\hline Residents' life & disposable income & RMB \\
\hline Energy consumption & $\begin{array}{l}\text { consumption expenditure } \\
\text { electric consumption } \\
\text { highway mile }\end{array}$ & $\begin{array}{c}\text { RMB } \\
100 \text { million kWh } \\
10,000 \mathrm{~km}\end{array}$ \\
\hline Circulation & $\begin{array}{l}\text { ownership vehicles } \\
\text { freight volume }\end{array}$ & $\begin{array}{l}10,000 \text { units } \\
10,000 \text { tons }\end{array}$ \\
\hline Urbanization level & $\begin{array}{l}\text { construction area } \\
\text { Proportion of urban population to } \\
\text { permanent population } \\
\text { R\&D personnel }\end{array}$ & $\begin{array}{c}10,000 \text { hectares } \\
\%\end{array}$ \\
\hline Science and technology and education & $\begin{array}{l}\text { Students in primary education } \\
\text { Students in secondary education }\end{array}$ & Person \\
\hline
\end{tabular}




\subsection{Methods}

EF is herein divided into six land types mentioned above. Equivalence and yield factors in each city are calculated to align the measurement unit [2]. The calculation formulas are shown as follows:

$$
\begin{gathered}
E F=N \times \sum_{i}\left(e f_{i} \times r_{i}\right)=N \times \sum_{i} \sum_{j}\left(\frac{C_{i j}}{P_{i j}} \times \frac{\frac{\sum_{j}\left(C_{i j} \times \gamma_{i j}\right)}{S_{i}}}{\frac{\sum_{i} \sum_{j}\left(C_{i j} \times \gamma_{i j}\right)}{\sum_{i} S_{i}}}\right) \\
E C=N \times \sum_{i}\left(e c_{i} \times r_{i} \times y_{i}\right)=N \times \sum_{i}\left(S_{i} \times \frac{\frac{\sum_{j}\left(C_{i j} \times \gamma_{i j}\right)}{S_{i}}}{\frac{\sum_{j}\left(C_{i j} \times \gamma_{i j}\right)}{\sum_{i}\left(C_{i j} \times \gamma_{i j}\right)}} \times \frac{\frac{\sum_{j}\left(C_{i j}^{\prime} \times \gamma_{i j}\right)}{\sum_{i} S_{i}}}{S_{i}^{\prime}}\right)
\end{gathered}
$$

where $N$ is the population (cap); $e f$ is per capita $\mathrm{EF}\left(\mathrm{hm}^{2} / \mathrm{cap}\right) ; i$ is land use type; $j$ is an item produced or consumed; $r_{i}$ is the equivalence factor of $i$ th land; $C_{i j}$ is per capita production or consumption of $j$-th item in $i$-th land in the study area $\left(\mathrm{kg} / \mathrm{cap} ; \mathrm{m}^{3} / \mathrm{cap} ; \mathrm{GJ} / \mathrm{cap}\right) ; P_{i j}$ is the average production or consumption of $j$-th item in $i$-th land in the world $\left(\mathrm{kg} / \mathrm{hm}^{2} ; \mathrm{m}^{3} / \mathrm{hm}^{2} ; \mathrm{GJ} / \mathrm{hm}^{2}\right) ; \gamma_{i j}$ is the average calorific value of $j$-th item in $i$-th land $\left(\mathrm{GJ} / \mathrm{hm}^{2}\right)$; and $S_{i}$ is per capita biological production area of $i$-th land in the study area ( $\left.\mathrm{hm}^{2} / \mathrm{cap}\right) ; e c$ is per capita EC ( $\left.\mathrm{hm}^{2} / \mathrm{cap}\right) ; y_{i}$ is the yield factor of $i$-th land; $C_{i j}^{\prime}$ is per capita production or consumption of $j$-th item in $i$-th land in the upper level area $(\mathrm{kg} / \mathrm{cap}$; $\mathrm{m}^{3} / \mathrm{cap} ; \mathrm{GJ} / \mathrm{cap}$ ); and $S_{i}^{\prime}$ is per capita biological production area of $i$-th in the upper level area ( $\mathrm{hm}^{2} / \mathrm{cap}$ ). The equivalence and yield factors were calculated on urban scale based on the local productivity to describe heterogeneity between cities. Note that some land types in Hong Kong and Macao SAR have no biomass output, but still retain other ecosystem services more than provisioning [47]. Thus, their equivalence and yield factors are replaced by the values of neighboring cities to avoid the null value. Namely, factors in Hong Kong and Macao refer to the value of Shenzhen and Zhuhai respectively.

Shannon-Wiener Index, a popular diversity index in the field of ecology, is introduced to reflect the abundance and evenness of land demand or supply in a given region [48]. The corresponding formulas are as follows:

$$
\begin{aligned}
& H_{e f}=-\sum_{i}\left(P_{i}^{e f_{i}} \times \ln P_{i}^{e f_{i}}\right) \\
& H_{e c}=-\sum_{i}\left(P_{i}^{e c_{i}} \times \ln P_{i}^{e c_{i}}\right)
\end{aligned}
$$

where $H_{e f}, H_{e c}$ are Shannon-Wiener Index of $e f_{i}$ and $e c_{i}$, respectively. $P_{i}^{e f}, P_{i}^{e c}$ are proportions of the $i$-th land's $e f_{i}$ and $e c_{i}$. The index should be $\ln i$ if $E F$ and $E C$ evenly distributed in each land type.

$\mathrm{EF}_{\text {size }}$ and $\mathrm{EF}_{\text {depth }}$ are introduced to distinguish natural capital flow occupancy and capital stock consumption [12,14]. $\mathrm{EC}_{\text {intensity, }}$ an indicator of innovation and technological level, represents the potential carrying capacity coupled with social capital. Assuming that scientific and technological progress has positive multiplicative synergies effects on sustainable development [49,50], the minimum value of this factor is set at 1.00. It represents the ratio of technology level of a metropolis to the regional average value as productivity of social capital. The formulas are as follows:

$$
\begin{gathered}
E F_{\text {size }}=N \times e f_{\text {size }}=N \times \sum_{i} \min \left\{e f_{i}, e c_{i}\right\} \\
E F_{\text {depth }}=e f_{\text {depth }}=1+\frac{\sum_{i} \max \left\{e f_{i}-(1-12 \%) \times e c_{i}, 0\right\}}{\sum_{i} e c_{i}} \\
E C_{\text {intensity }}=\sqrt[3]{\left(1+\frac{P_{k}}{P_{k}^{\prime}}\right) \times\left(1+\frac{M_{k}}{M_{k}^{\prime}}\right) \times\left(1+\frac{F_{k}}{F_{k}^{\prime}}\right)} \\
E D_{3 D}=E C \times E C_{\text {intensity }}-E F_{\text {size }} \times E F_{\text {depth }}
\end{gathered}
$$


where $E F_{\text {size }}, e f_{\text {size }}$ are ecological footprint size $\left(\mathrm{hm}^{2}\right)$ and per capita ecological footprint size $\left(\mathrm{hm}^{2} / \mathrm{cap}\right)$; $E F_{\text {depth }}$ and $e f_{\text {depth }}$ are the same meaning of ecological footprint depth; according to Our Common Future, $12 \%$ of the total land use is set aside for biodiversity protection. $E C_{\text {intensity }}$ is ecological carrying capacity intensity. $k$ is the city, $P_{k}, M_{k}, F_{k}$ are the numbers of patent applications, researchers and funds of R\&D per thousand persons in $k$-th city in the study area, respectively(item/thousand persons, person/thousand persons, RMB/thousand persons); $P_{k^{\prime}}^{\prime} M_{k^{\prime}}^{\prime} F_{k}^{\prime}$ are the numbers of patent applications, researchers and funds of R\&D per thousand persons in the upper level area, respectively(item/thousand persons, person/thousand persons, $\mathrm{RMB} /$ thousand persons); $E D_{3 D}$ is the three-dimensional ecological deficit $\left(\mathrm{hm}^{2}\right)$, consistently meaning ecological surplus if $E D_{3 D}>0$ and deficit if $E D_{3 D}<0$.

PLS regression could synchronously represent the characteristics of principal component analysis, canonical correlation analysis and linear regression analysis. Compared with the traditional multiple linear regression model, PLS is particularly useful when the fewer independent variables are seriously multicollinearity [51]. Using the variable importance in projection (VIP) analysis of PLS regression [52], the value of each index reflects the effect on dependent variable. The calculation formula is as follows:

$$
V I P_{j}=\sqrt{\frac{p \sum_{h=1}^{m} R d\left(Y ; t_{h}\right) w_{h j}^{2}}{R d\left(Y ; t_{1}, \cdots, t_{m}\right)}}
$$

where $V I P_{j}$ is VIP of $j$ th indicator to represent the explanatory power of each independent variable to the dependent variable, $p$ is the number of selected indices, $m$ is pairs of extracted PLS principal component, $R d\left(Y ; t_{h}\right)$ represents explanatory power to $Y$ of the axis $t_{h}, w_{h j}$ denotes the weight of $j$-th variable when mapping in the $h$-th iteration, $\operatorname{Rd}\left(Y ; t_{1}, \cdots, t_{m}\right)$ represents cumulative explanatory power to $Y$ of the axis $t_{1}, \cdots, t_{m}$. VIP values greater than 1.00 indicate independent variables are important factors, the variables with VIP value of $0.50-1.00$ are the less important factors, and the variables with VIP value lower than 0.50 are not important factors [52]. Regression coefficient is also an important index to measure the effect of variables. With the increase of absolute value of coefficient, it shows that the influence degree of the variable is stronger. The regression coefficient is positive, which means that the dependent variable is positively correlated with the independent variable, and vice versa. Therefore, by analyzing the VIP values and the regression coefficients, the influence of each independent variable index on dependent variable can be directly expressed.

\section{Results}

\subsection{Analysis of Ecological Footprint Size}

$\mathrm{EF}_{\text {size }}$ represented the natural capital flow occupancy. Higher per capita $\mathrm{EF}_{\text {size }}$ concentrated in regions with abundant resources and low population density, while lower values were more likely to occur in populous areas with scarce utilizable lands. Yearly average per capita $\mathrm{EF}_{\text {size }}$ of 11 cities were ranked as follows: Zhaoqing $>$ Jiangmen $>$ Huizhou $>$ Shenzhen $>$ Zhongshan $>$ Guangzhou $>$ Foshan $>$ Zhuhai $>$ Hong Kong $>$ Dongguan $>$ Macao (Figure 2). Temporal-spatial characteristic differences amongst cities were relatively large with the highest value was $0.46 \sim 0.52 \mathrm{hm}^{2} / \mathrm{cap}$ in Zhaoqing and lowest in Macao $\left(<0.01 \mathrm{hm}^{2} / \mathrm{cap}\right)$. Per capita $\mathrm{EF}_{\text {size }}$ in Zhaoqing, Jiangmen and Zhongshan presented an upward trend while Shenzhen, Hong Kong, Guangzhou and Foshan showed a downward trend especially during 2014-2016. Cities of large territory and sparse population owned higher per capita $\mathrm{EF}_{\text {size }}$ represented a more sustainable development with local natural capitals. 


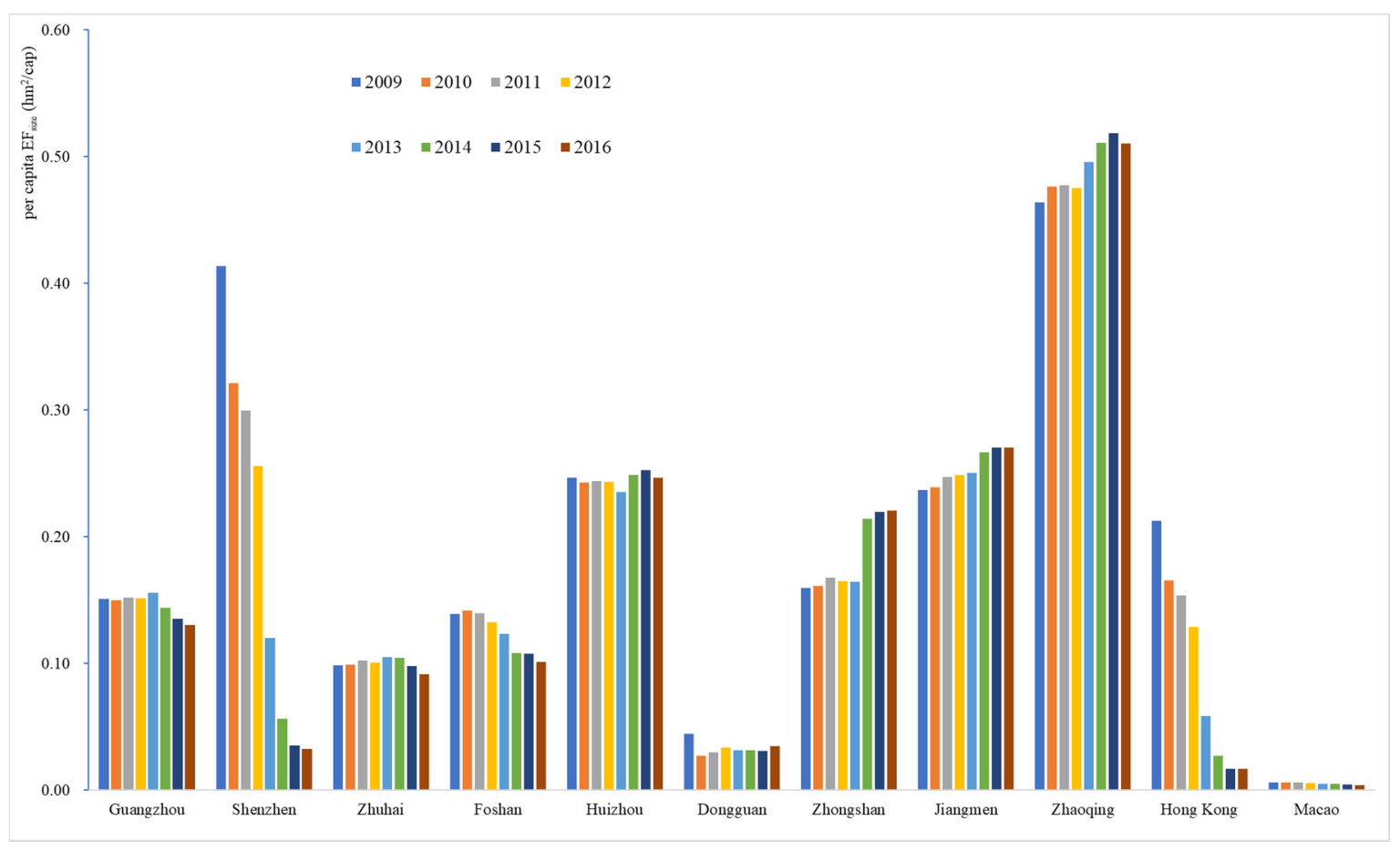

Figure 2. Per capita Ecological footprint size (per capita $\mathrm{EF}_{\text {size }}$ ) of each city in GHMGBA.

$\mathrm{EF}_{\text {size }}$ of six land types with different proportions in each metropolis were further analyzed (Figure 3). Fossil energy consumption was the most important natural capital stock utilization while no excess land was reserved to absorb carbon dioxide according to $\mathrm{EF}$ theory. Thus, $\mathrm{EF}_{\text {size }}$ of fossil energy land in 11 cities was set as zero. Among the other five lands, cropland and construction land components contributed greatly to total $\mathrm{EF}_{\text {size. }}$. Cropland $\mathrm{EF}_{\text {size }}$ of Zhaoqing, Jiangmen and Huizhou accounted for 45.69 66.99\%. The dominant land in Macao, Hong Kong, Shenzhen and Dongguan was construction land (74.29 100.00\%). Grassland and woodland $\mathrm{EF}_{\text {size }}$ had minimal impacts on GHMGBA except for Zhaoqing.

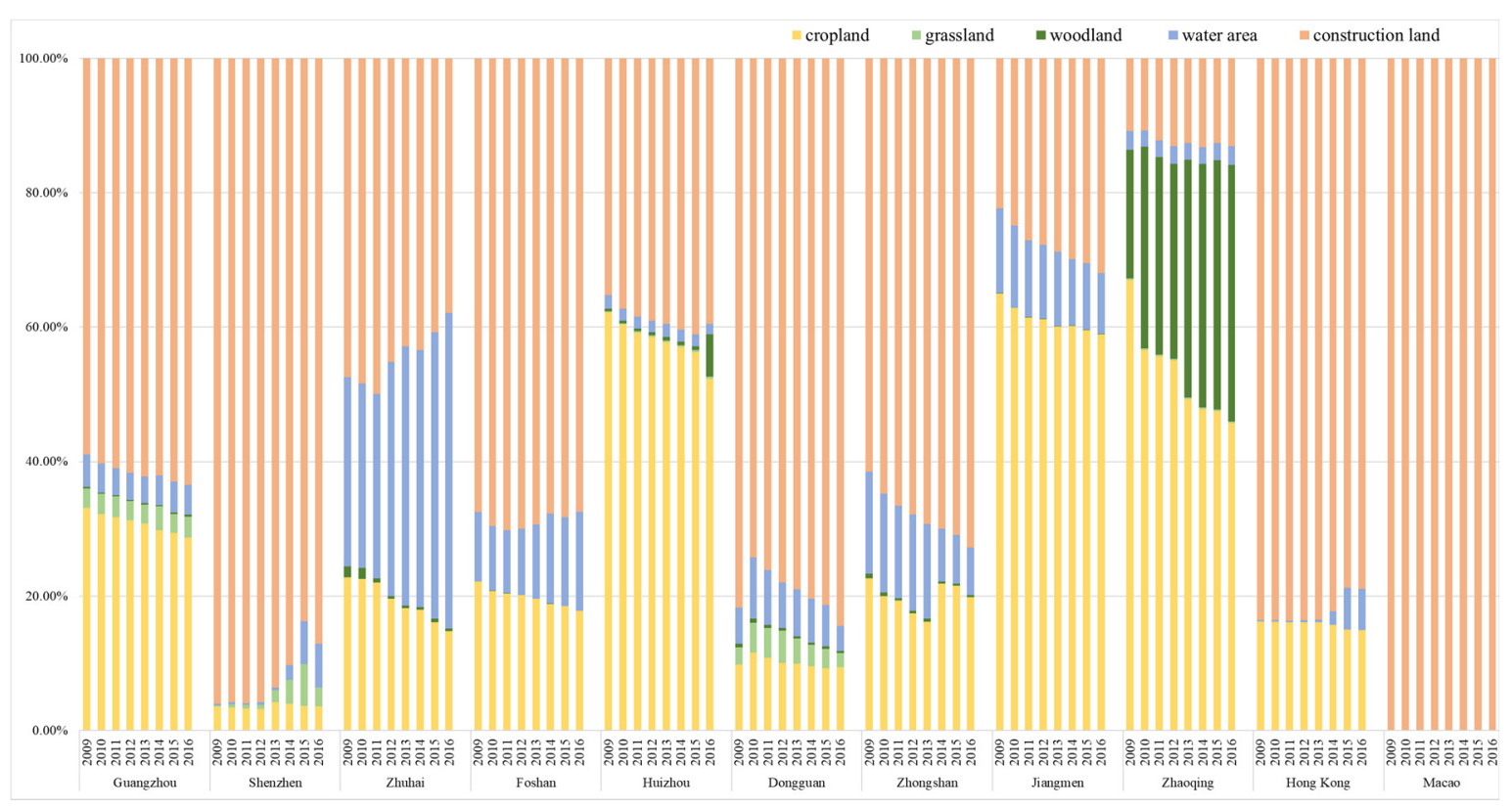

Figure 3. $\mathrm{EF}_{\text {size }}$ composition ratio of 11 cities in GHMGBA. 
Analysis of the diversity index found that land types of $\mathrm{EF}_{\text {size }}$ between cities were significantly different. Shannon-Wiener Index in Macao was zero due to null values of cropland, grassland, woodland and water area, followed by Shenzhen (0.18 0.62) and the highest value was Zhaoqing $(0.94 \sim 1.11)$. There existed a certain degree of land complementarity amongst cities. Generally, it was difficult to maintain sustainable development relying purely on local natural resources in modern society nowadays. In particular, lands of Hong Kong and Macao were significantly insufficient, and most of the resources depended heavily on provisions from Mainland China.

\subsection{Analysis of Ecological Footprint Depth}

All cities of GHMGBA were in deficit state with $\mathrm{EF}_{\text {depth }}$ much larger than 1.00, showing capital flow could not meet the needs and capital stock was heavily occupied. The multi-year average $\mathrm{EF}_{\text {depth }}$ were ranked as follows: Zhongshan $<$ Zhaoqing $<$ Guangzhou $<$ Jiangmen $<$ Foshan $<$ Huizhou $<$ Shenzhen $<$ Zhuhai $<$ Hong Kong $<$ Dongguan $<$ Macao (Figure 4). The maximum $\mathrm{EF}_{\text {depth }}$ was 17.11 26.21 for Macao with larger population and deficient land while the minimum was 2.42 3.58 for Zhongshan. Contrary to the curve of per capita $\mathrm{EF}_{\text {size, }}$ Shenzhen held the lowest $\mathrm{EF}_{\text {depth }}$ in 2009 (1.85) and rapidly reached 12.29 in 2016 with the largest annual growth rate $(31.10 \%)$. $\mathrm{EF}_{\text {depth }}$ of Macao was with a U-shaped trend reaching a minimum of 17.11 in 2013 while Dongguan held an inverted U-shaped curve.

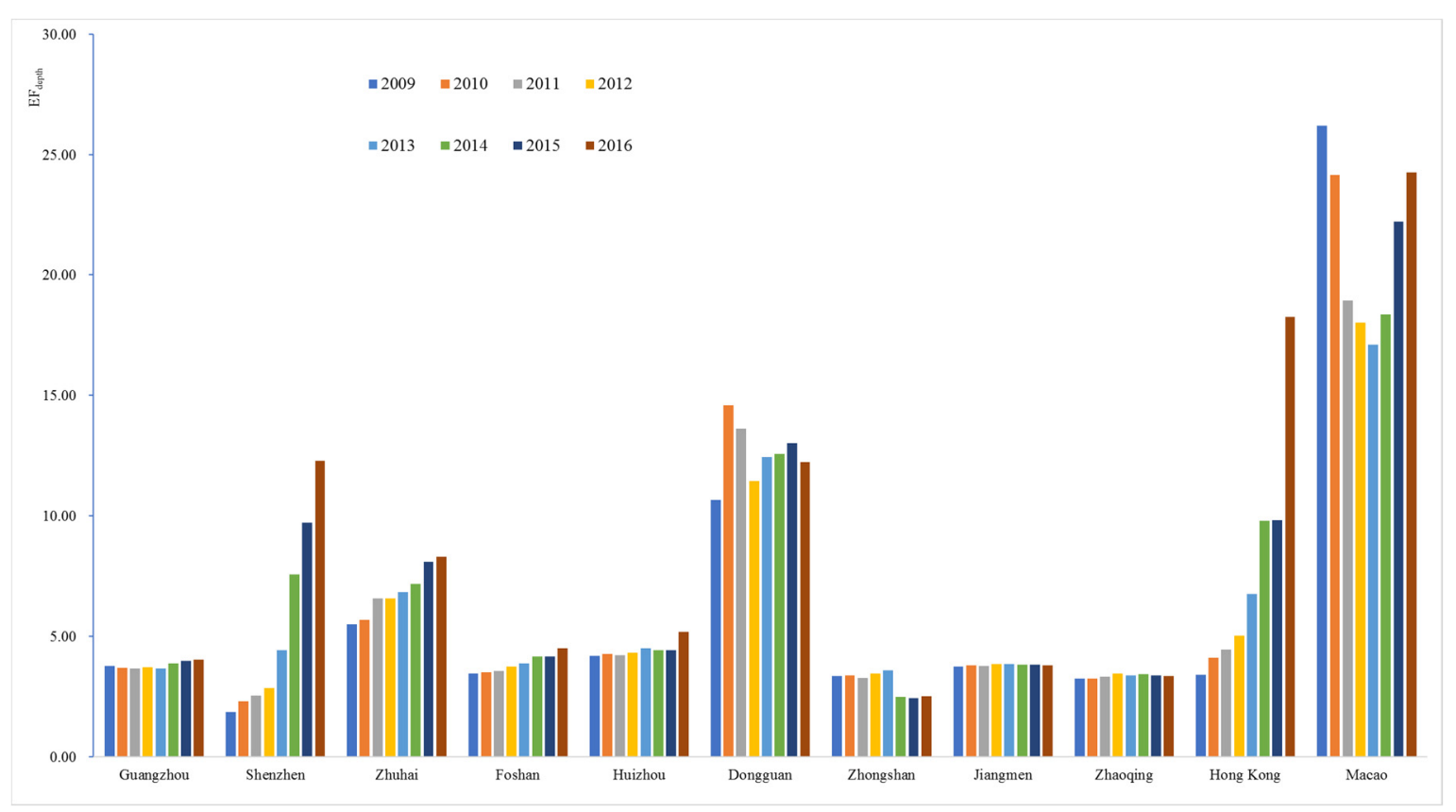

Figure 4. Ecological footprint depth $\left(\mathrm{EF}_{\mathrm{depth}}\right)$ of 11 cities in GHMGBA.

$\mathrm{EF}_{\text {depth }}$ component ratios in 11 cities were further analyzed. The deficit of cropland, fossil energy and construction land were primary parts affecting $\mathrm{EF}_{\text {depth }}$. Cropland constituted $62.16 \sim 76.01 \%$ in Zhaoqing, Jiangmen and Huizhou while construction land dominated (60.40 76.02\%) in Shenzhen, Hong Kong and Macao. Construction land was in a slight surplus for Zhongshan, Jiangmen and Zhaoqing due to their abundant impervious areas. Industrial scope and intensity in urbanization process alleviated municipal ecological pressures besides the transformation of other type lands into construction land. The proportion of water area was followed by 19.61 33.64\% in Jiangmen, Zhongshan, Foshan and Zhuhai. Regarding the grassland composition, $\mathrm{EF}_{\text {depth }}$ in Hong Kong and Macao were 1.00, consuming only the natural capital flow of meadow due to scant local livestock products. Woodlands of 11 cities were in surplus but with a downward trend during the study period, largely owing to the forestry protection policy in GHMGBA. 


\subsection{Analysis of Ecological Carrying Capacity Intensity}

$\mathrm{EC}_{\text {intensity }}$ exceeded the reference value of 1.00 in all cities, indicating a higher level of supportability (Figure 5). This showed that social capital could improve regional resource coordination to meet higher ecological demands. With the social progress in GHMGBA, scientific and technological innovation capabilities improved gradually. The innovation ability in backward areas appeared to increase with higher sensitivity than developed regions. $\mathrm{EC}_{\text {intensity }}$ differed significantly among cities and the values in developed cities were much higher similar to Matthew Effect. As the core innovative metropolis

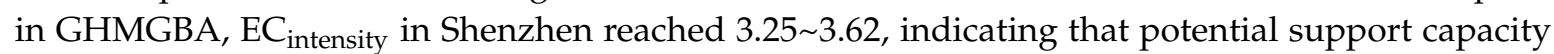
multiplied more than threefold compared to that of natural capital solely. The next were Zhongshan (2.61 2.80) and Zhuhai (2.35 2.65) directly related to higher proportions of researchers and patents. EC $_{\text {intensity }}$ in Hong Kong (2.02 2.71) was followed due to affluent funds with a downward trend similar to Shenzhen. The lowest was in Macao (1.29 1.37), with fewer patents, funds, and technicians, resulting in weaker innovation capacity in GHMGBA.

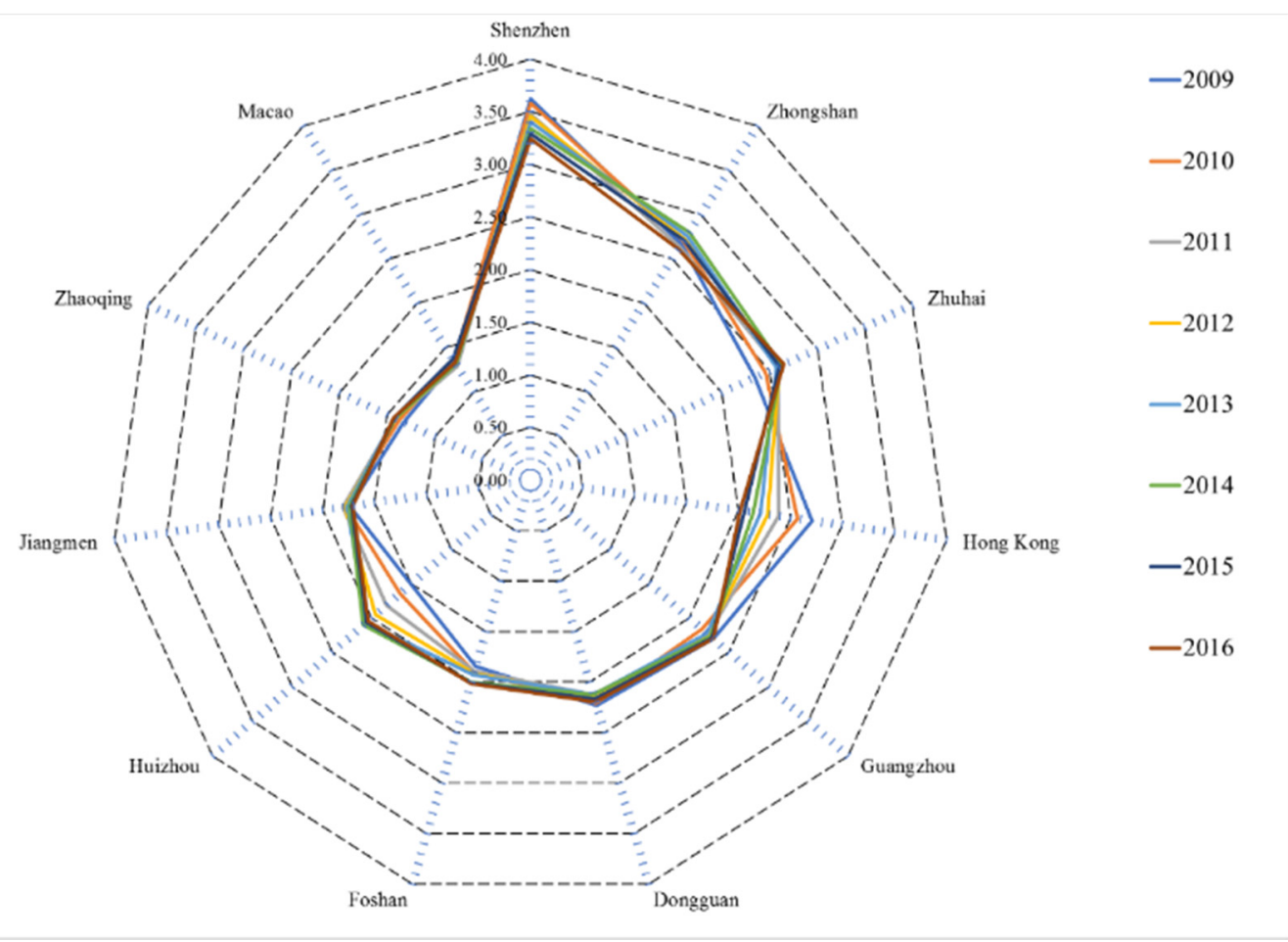

Figure 5. $\mathrm{EC}_{\text {intensity }}$ of 11 cities in GHMGBA.

\subsection{Analysis of Three-Dimensional Ecological Deficit}

$\mathrm{ED}_{3 \mathrm{D}}$ in 11 cities were calculated. As shown in Figure 6, there was no obvious spatial agglomeration with an aggravated trend from the periphery to the center. Average per capita $\mathrm{ED}_{3 \mathrm{D}}$ of Zhongshan and Shenzhen exceeded $0.00 \mathrm{hm}^{2} / \mathrm{cap}$ with a surplus state and the other nine cities were in deficit. Values in Zhaoqing and Huizhou were the largest reaching $-0.65 \sim-0.61 \mathrm{hm}^{2} / \mathrm{cap}$. Per capita $\mathrm{ED}_{3 \mathrm{D}}$ in Shenzhen dramatically decreased from $0.74 \mathrm{hm}^{2} / \mathrm{cap}$ to $-0.29 \mathrm{hm}^{2} /$ cap and turned surplus into deficit in 2013 . Zhongshan transformed into a deficit state in 2012 and reversed into surplus in 2014 due to higher EC. $\mathrm{ED}_{3 \mathrm{D}}$ of Jiangmen, Zhuhai, and Zhaoqing fell rapidly and stayed in deficit during the study period. 


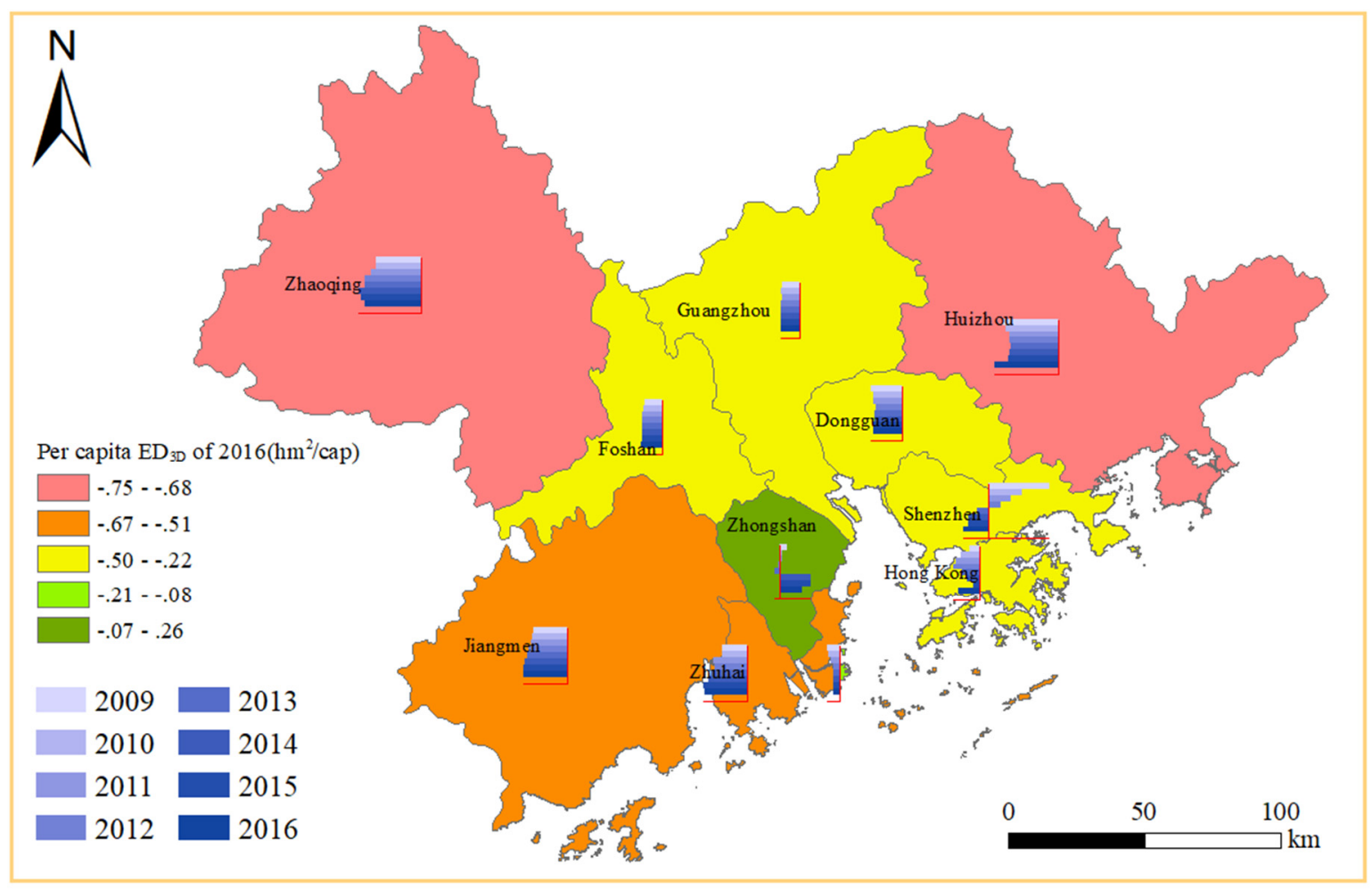

Figure 6. Per capita $\mathrm{ED}_{3 \mathrm{D}}$ of 11 cities in GHMGBA.

\section{Discussion}

\subsection{Spatial Analysis of Natural Capital Utilization}

Distribution of average per capita $\mathrm{EF}_{\text {size }}$ and $\mathrm{EF}_{\text {depth }}$ of 11 cities in GHMGBA was analyzed. It could be found there was a significant regional complementarity between capital stock consumption and capital flow occupation. Per capita $\mathrm{EF}_{\text {size }}$ of 11 cities arranged in descending order according to $\mathrm{EF}_{\text {depth }}$ showed an upward trend. Results showed depletion of capital stock became prevailing along with the socioeconomic development in GHMGBA.

Per capita $\mathrm{EF}_{\text {size }}$ and $\mathrm{EF}_{\text {depth }}$ of each year in 11 cities were standardized to be compared through the Z-Score method, and hierarchical clustering analysis was carried out using SPSS 23.0 (IBM, Armonk, NY, USA). According to the difference of per capita $\mathrm{EF}_{\text {size }}$ and $\mathrm{EF}_{\text {depth }}$ values, natural capital utilization patterns were intuitively classified into four types and results were spatially distributed in Figure 7. Cities of type I represented highest $\mathrm{EF}_{\text {depth }}$ and lowest $\mathrm{EF}_{\text {size }}$; type II held higher $\mathrm{EF}_{\text {depth }}$ and lower $\mathrm{EF}_{\text {size }}$; type III owned lower $\mathrm{EF}_{\text {depth }}$ and higher $\mathrm{EF}_{\text {size }}$; type IV implied lowest $\mathrm{EF}_{\text {depth }}$ and highest $\mathrm{EF}_{\text {size. }}$. From type I to type IV, the consumption of capital stock was reduced while capital flow was richer, which indicated superior ecological sustainability. The capital utilization types in some cities changed during the study period. Shenzhen gradually converted from type IV to type II, and Hong Kong transformed from type III to type I, representing a deteriorating trend of capital stock consumption. The zoning of capital utilization illustrated a significant geographical agglomeration, which was consistent with the spatial distribution of the natural endowments and socioeconomic status in GHMGBA. Long time series analysis should be continued particularly on multiple scales for more empirical conclusions. Policy decisions could not be made according to certain years, but that still showed a highly severe trend in GHMGBA. 


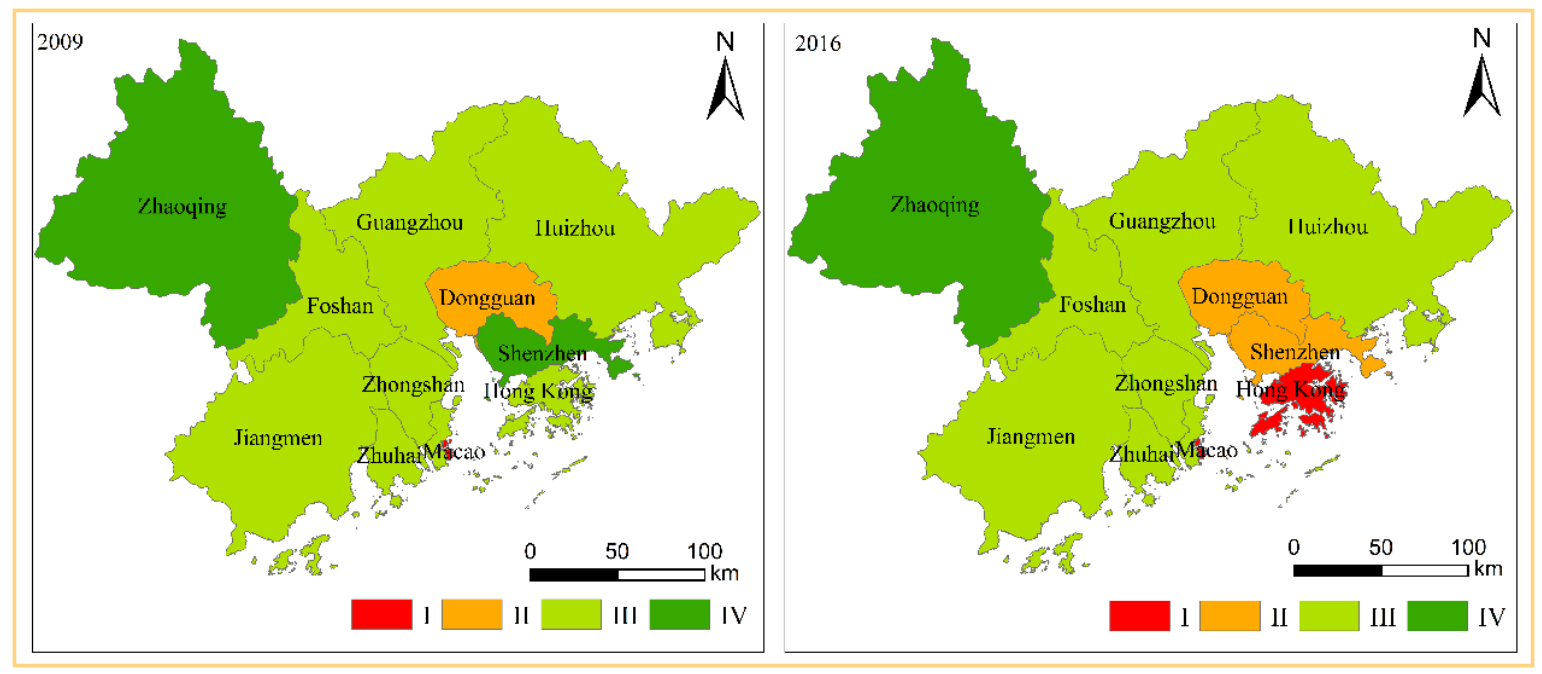

Figure 7. Natural capital utilization patterns between 2009 and 2016 in GHMGBA.

The spatial characteristic of land supply and demand pattern is consistent with previous researches. GHMGBA was in severer deficit state and overconsumption of capital stock continued during the study period. According to the reports of Great Bay Areas in the world, the degree of resource depletion $\left(\mathrm{EF}_{\text {depth }}\right)$ ranked as San Francisco $>$ New York $>$ Kawasaki $>$ Hong Kong $>$ Macao $>$ PRD $>$ GHMGBA $>$ world $[8,10,28,53]$. In addition to the inconsistency of data, the conclusion difference is directly associated with the localization of weight parameters $[41,54,55]$. The majority of natural resources in GHMGBA is transferred through imports [28,55]. EF in Hong Kong reached $3.7 \mathrm{hm}^{2} /$ cap excluding forest area for fossil fuel emissions while more than $90 \%$ pressure was located outside the region. Vegetable consumption of Hong Kong was 850 kilotons while its local production was only 14 kilotons in 2016. Macao barely has primary industry and correspondingly its EF has been transferred to other regions. Compared with other cities, Hong Kong and Macao are relatively barren inland output productivity. Thus, it is more reliable to depict cropland, grassland, woodland, water area EF by production rather than consumption. On the whole, the difference between this research and previous studies is still within a reasonable range.

\subsection{Driving Factors Analysis of Ecological Footprint and Carrying Capacity}

Variance inflation factors of the indicators were all greater than 10.00, indicating that there was serious multicollinearity between these selected indicators. Thus, PLS model was explored to analyze driving factors of $\mathrm{EF}_{\text {depth }}, \mathrm{EC}_{\text {intensity }}$ and per capita $\mathrm{ED}_{3 \mathrm{D}}$ in GHMGBA.

The explanatory fit degrees of PLS models in 2009-2016 were explored (Table 3), showing that the regional differentiation characteristics in GHMGBA were relatively significant. Based on variable importance projection (VIP) and regression coefficients of driving factors, the crucial driving factors of $\mathrm{EF}_{\text {depth}}, \mathrm{EC}_{\text {intensity }}$ and $\mathrm{ED}_{3 \mathrm{D}}$ during the study period were students in primary and secondary education, residents' income and consumption, R\&D personnel, freight volume, etc.

The escalation of students in primary education indicates the continuous improvement of local permanent population and educational resources. The vigorous development of catering, training, science and education, entertainment, sports and other industries affiliated to the campus further promotes continuous occupation of natural capital flow and stock. With the promotion of compulsory education in China, the average number of pupils in 11 cities increased from 382,787 in 2009 to 468,188 in 2016. Under the trade-off of $\mathrm{EF}_{\text {depth }}$ and $\mathrm{EC}_{\text {intensity, }}$ the number of pupils was generally positively related to per capita $\mathrm{ED}_{3 \mathrm{D}}$ with a regression coefficient of 4.23E-9, indicating that the deficit state was ameliorated. There was a negative correlation in Type I and III cities, and a positive correlation in Type II and IV cities; there took a negative correlation in Guangzhou, Shenzhen, Zhuhai, Foshan, and Jiangmen, and positively related in Dongguan, Zhongshan, Zhaoqing and Macao; indicating 
that the increase in the number of pupils in most cities tended to worsen the ED. It was necessary to strengthen the awareness of ecological environment protection and promote low-carbon life concepts among primary students.

Table 3. PLS model fit of $\mathrm{EF}_{\text {depth}}, \mathrm{EC}_{\text {intensity }}$ and per capita $\mathrm{ED}_{3 \mathrm{D}}$ in GHMGBA.

\begin{tabular}{cccc}
\hline Municipality & EF $_{\text {depth }}$ & EC $_{\text {intensity }}$ & Per Capita $\mathbf{E D}_{\text {3D }}$ \\
\hline Guangzhou & 0.94 & - & 0.14 \\
Shenzhen & 0.99 & 0.97 & 0.90 \\
Zhuhai & 0.93 & 0.77 & 0.88 \\
Foshan & 0.95 & 0.89 & 0.89 \\
Huizhou & 0.58 & 0.94 & - \\
Dongguan & - & 0.08 & 0.82 \\
Zhongshan & 0.65 & - & 0.61 \\
Jiangmen & 0.61 & 0.87 & 0.98 \\
Zhaoqing & 0.87 & 0.92 & 0.98 \\
Hong Kong & 0.86 & 0.97 & - \\
Macao & 0.92 & - & 0.92 \\
\hline
\end{tabular}

With the implementation of China's family planning policy, the birth population continued to decrease in the 1990s and early 20th century, which led to lower age-appropriate middle school students during the study period. A great many students from outside Guangdong Province go to primary schools in developed areas, but they cannot straight attend high school due to household registration restriction. If the migrants could continue to study, their family income was generally higher, otherwise, they cannot pay for local borrowing fees, school selection fees, agency fees and other expenses, which were related to residents' disposable income. In Type I and III cities, there was a negative correlation between the number of middle school students and per capita $\mathrm{ED}_{3 \mathrm{D}}$ while positive in Types II and IV ones, and the regression coefficients were greater than the former. Results showed that the increase of students in secondary education in most cities tended to the deterioration of per capita $\mathrm{ED}_{3 \mathrm{D}}$, which was consistent with the results of students in primary education.

As a frontier position for China's reform and opening up, economic growth in GHMGBA exploded in recent years. The annual per capita disposable income of residents increased significantly. VIP value indicated that it was the most important driving factor in Macao and the second most important factor in Hong Kong and Zhuhai. Generally, disposable income was positively correlated with per capita $\mathrm{ED}_{3 \mathrm{D}}$. The income had the most important impact on the deficit in Dongguan and Macao and their regression coefficients were positive. There showed lower negative regression coefficients in Guangzhou, Shenzhen, Zhongshan, Jiangmen with smaller VIP values, indicating that the increase in residents' income had a large positive effect on amelioration of ED.

EF theory takes human consumption as the starting point, so the level of residents' consumption has a direct impact on natural capital utilization. Consumption expenditure and per capita $\mathrm{ED}_{3 \mathrm{D}}$ were positively correlated with the regression coefficient of 5.28E-7. Coefficients in Type I, III, and IV cities reached 4.27E-7, 4.70E-6, and 3.53E-5, higher than the negative coefficient of $-2.25 \mathrm{E}-05$ in Type II cities. The results showed that ED tended to be ameliorated with an increase in consumption expenditure, mainly benefiting from the potential supporting capacity of social capital.

The level of technology innovation has a significant positive effect on regional sustainable development. R\&D personnel in 11 cities increased dramatically, with a growth rate of $117.20 \%$. R\&D personnel and per capita $\mathrm{ED}_{3 \mathrm{D}}$ were positively correlated in GHMGBA with a regression coefficient of 2.55E-6. VIP value of R\&D personnel in Dongguan was next to disposable income, indicating investment of scientific and technological manpower had a significant amelioration effect on deficit state; while negative coefficients were found in Guangzhou, Shenzhen, and Zhuhai, showing the escalation in R\&D personnel had a stronger effect on EF expansion than potential carrying capacity of social capital, which may be related to lag effect of technological productivity. 
Freight volume can reflect the resource circulation among regions. The average volume of 11 cities increased from 138.55 million tons in 2009 to 255.20 million tons in 2016; the growth rates of developed cities such as Hong Kong (3.68\%) and Shenzhen (41.97\%) were lower while Macao showed a negative rate $(-18.05 \%)$, which reflected the coupling relationship between material transportation scale and economic level in various cities. Regression coefficients of Types I, II, III, and IV between freight volume and per capita $\mathrm{ED}_{3 \mathrm{D}}$ were positive, representing an important driving factor in ameliorating the deficit state of natural capital. Similar to $\mathrm{EC}_{\text {intensity, }}$ positive PLS regression coefficients of Foshan, Dongguan and Zhaoqing were higher than the negative values of other cities, indicating that increase of freight volume tended to ameliorate regional deficit. Economically developed areas could transfer their EF to other regions and the degree of dependence on resource import significantly increased, meaning these metropolises should strengthen international cooperation.

Due to the unavailability of panel data, the relationship between economic development and ecological deficit needs to be further verified, especially accounting for factors such as technological innovation, residents' living patterns, and talent policies. Industrial policy formulation needs to weigh the coupling relationship between $\mathrm{EF}_{\text {depth }}$ and $\mathrm{EC}_{\text {intensity }}$.

\subsection{Implications for Ecological Deficit Mitigation}

The proposal of GHMGBA was of great significance to national strategies such as The Belt and Road Initiative. Occupancy ratios of natural capital flow and stock in GHMGBA were depicted based on 3DEF model. Contradiction between resource consumption and land supply could be

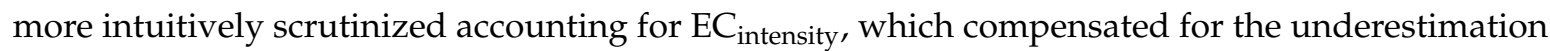
of traditional EF model on human subjective initiative. Prior researches indicated that developed regions were likely more unsustainable $[16,19,34]$, which was inconsistent with the reality of social development. The introduction of $\mathrm{EC}_{\text {intensity }}$ coupling with social components bridged this gap. Therefore, pinpointing policy recommendations could be put forward to implement national strategies according to local ecological status in different cities.

Enhancing EC of specific regions should simultaneously promote $\mathrm{EF}_{\text {size }}$ and $\mathrm{EC}_{\text {intensity }}$ and also reduce $\mathrm{EF}_{\text {depth }}$. $\mathrm{EF}_{\text {size }}$ is predominated by natural capital, $\mathrm{EC}_{\text {intensity }}$ is decided by technological innovation and $\mathrm{EF}_{\text {depth }}$ is widely affected by resource consumption. Thus, it is necessary to lessen resource consumption, optimize industrial structure through technical reform and resident lifestyle. Previous researchers found that GHMGBA was unsustainable during past decades. We conducted an empirical study taking the potential productivity of science and technology into account. Innovation in information technology and cross-sectoral collaboration would be key to reduce the human footprint [56]. As one of the most developed regions in China, the impact of transportation and tourism in GHMGBA could not be neglected $[57,58]$. Sustainable development of modern fisheries must be strengthened with a vast tract of the ocean $[59,60]$. Integrated land use planning needs to actively explore accounting for resources coupled with public participation and green consumption [61,62]. Each city should optimize industrial structures to promote economy based on local natural endowments. Jiangmen and Zhaoqing should determinedly implement the crucial concepts "lucid waters and lush mountains are invaluable assets", while Hong Kong and Shenzhen focus on scientific innovation and integrated management to improve resource utilization efficiency. It is urgent to profitably allocate resources for energy efficiency and conservation projects to moderate environmental degradation [63,64]. Financial development especially cross-border investment is a potential instrument to preserve the environment providing better chances to get advanced technologies and energy-efficient products [31,65]. Public promotion should be strengthened to improve living lifestyle $[66,67]$. However, due to limited number of years selected in the cross-sectional data, relationship between economy and ED requires further verification, especially when considering technology and lifestyle $[68,69]$. The policy portfolios toward sustainable development should be made considering the balance between $\mathrm{EF}_{\text {depth }}$ and $\mathrm{EC}_{\text {intensity }}$. 


\subsection{Uncertainty Analysis of $E C_{\text {intensity }}$}

The EF model has been discussed by many scholars these years [70,71]. In addition to the natural capital, the impact of science and technology on regional EC could not be ignored during rapid socioeconomic development [72]. There are few quantitative studies on EC of social capital. The lifestyle and production mode of residents in all aspects have profoundly changed especially in the information age. This paper constructs $\mathrm{EC}_{\text {intensity }}$ based on technological innovation level to represent the potential carrying capacity of social capital.

With the development of science and technology, the proportion of facilities farming, hydroponics, modern fisheries and clean energy is increasing [60,73,74]. The yield of major crops in GHMGBA has increased greatly over the past few years, especially the output of economic crops, fruits and aquatic products (16.83-113.12\%). Spatial expansion is achieved through modern technology, greatly broadening the actual land area. With abundant natural resources combined with convenient circulation and preferential policies based on scientific support, the population in GHMGBA has increased from 61 million to 73 million in the past decade. The high growth of the number of primary and secondary school students laterally shows the attraction of the region. While the average annual decrease rate of energy consumption for GDP reaches $4.20 \%$ during 2010-2019. This study conducted an empirical study and $\mathrm{EC}_{\text {intensity }}$ could be complementary to the traditional model. It is the correction of yield factors coupling with social capital within social-economic-natural complex ecosystem.

$\mathrm{EC}_{\text {intensity }}$ can reflect the ability of scientific and technological innovation, but it has not directly considered the residents' lifestyle and policies. The personalized utilization of resources by the public has a great impact when estimating the most probable value of EC [62,75]. Resource allocation and policy interventions can effectively reduce the consumption rate especially in high-income countries or regions [76]. The tracking and investigation of specific behaviors could be strengthened, including multi-dimensional indicators such as age, disposable income, education level and preference of residents $[31,68,77,78]$. Further research should analyze the contribution of natural capital, innovation and policy through piecewise linear representation or decomposition model with long-time series data.

\section{Conclusions}

Based on the 3DEF model, per capita $\mathrm{EF}_{\text {size }}$ and $\mathrm{EF}_{\text {depth }}$ of 11 cities in GHMGBA during 2009-2016 were analyzed. $\mathrm{EC}_{\text {intensity }}$ was introduced as a potentiality for sustainable development to avoid underestimated evaluations. There depicted a distinctive state of ES/ED in various cities; And most of them held relatively higher ecological pressure, even considering the potential productivity of technological innovation. The introduced parameter $\left(\mathrm{EC}_{\text {intensity }}\right)$ emphasized the subjective initiative of human beings, which was more consistent with the reality of social and economic development. The growth of students in primary and secondary education would aggravate the consumption of local resources and tend to worsen ED for most cities. Increment of disposable income, consumption expenditure and freight volume had a greater positive effect on ameliorating the ecological deficit. While R\&D personnel had a stronger effect on footprint expansion than the potential carrying capacity of social capital in most cities. Policy suggestions were proposed in the aspects of industrial structure, technology promotion and environmental protection publicity to achieve harmony between nature and human beings.

The estimation and driving force analysis for per capita $\mathrm{ED}_{3 \mathrm{D}}$ should be further researched, especially taking social capital into account. EF and EC inventory should be established for more accurate results with long-time series panel datasets. Hysteretic effects of technology promotion and information exchange could not be ignored. Source and sink relationships are difficult to identify due to inaccessible trade data. As the developed metropolitan statistical area, GHMGBA plays an important "sink" role for neighboring regions. Our findings are beneficial to provide basic support for coordination of capital utilization and economic development in GHMGBA and other similar regions. 
Author Contributions: Y.-N.W. conceived and performed the research. Q.Z. participated in data collection and paper correction. Y.-N.W. and Q.Z. wrote and revised the manuscript. H.-W.W. conceived and made valuable comments and suggestions on the paper. All authors have read and agreed to the published version of the manuscript.

Funding: This research is supported by the Strategic Priority Research Program (A) of the Chinese Academy of Sciences (XDA23030103), National Natural Science Foundation of China (41571148) and the National Key R\&D Program of China (2016YFC0501101).

Acknowledgments: The authors would like to thank Jingzhu Zhao at the Institute of Urban Environment, Chinese Academy of Sciences for the helpful guidance to greatly improved the manuscript. The authors also thank the anonymous referees for their instructive comments.

Conflicts of Interest: The authors declare no conflict of interest.

\section{References}

1. Ress, W.E.; Wackernagel, M. Ecological Footprints and Appropriated Carrying Capacity: Measuring the Natural Capital Requirements of the Human Economy. Focus 1996, 6, 45-60. [CrossRef]

2. Wackernagel, M.; Rees, W.E. Perceptual and structural barriers to investing in natural capital: Economics from an ecological footprint perspective. Ecol. Econ. 1997, 20, 3-24. [CrossRef]

3. Galli, A.; Kitzes, J.; Niccolucci, V.; Wackernagel, M.; Wada, Y.; Marchettini, N. Assessing the global environmental consequences of economic growth through the Ecological Footprint: A focus on China and India. Ecol. Indic. 2012, 17, 99-107. [CrossRef]

4. Lane, M. The carrying capacity imperative: Assessing regional carrying capacity methodologies for sustainable land-use planning. Land Use Policy 2010, 27, 1038-1045. [CrossRef]

5. Mostafa, M.M. A Bayesian approach to analyzing the ecological footprint of 140 nations. Ecol. Indic. 2010, 10, 808-817. [CrossRef]

6. Wood, R.; Garnett, S. An assessment of environmental sustainability in Northern Australia using the ecological footprint and with reference to Indigenous populations and remoteness. Ecol. Econ. 2009, 68, 1375-1384. [CrossRef]

7. Borucke, M.; Moore, D.; Cranston, G.; Gracey, K.; Iha, K.; Larson, J.; Lazarus, E.; Morales, J.C.; Wackernagel, M.; Galli, A. Accounting for demand and supply of the biosphere's regenerative capacity: The National Footprint Accounts' underlying methodology and framework. Ecol. Indic. 2013, 24, 518-533. [CrossRef]

8. Zhang, K.; Fu, S.; Zhang, W. Ecological carrying capacity of 31 provinces based on improved ecological footprint model. Sci. Geogr. Sin. 2011, 31, 1084-1089. [CrossRef]

9. Yue, D.; Xu, X.; Hui, C.; Xiong, Y.; Han, X.; Ma, J. Biocapacity supply and demand in Northwestern China: A spatial appraisal of sustainability. Ecol. Econ. 2011, 70, 988-994. [CrossRef]

10. Geng, Y.; Zhang, L.; Chen, X.; Xue, B.; Fujita, T.; Dong, H. Urban ecological footprint analysis: A comparative study between Shenyang in China and Kawasaki in Japan. J. Clean. Prod. 2014, 75, 130-142. [CrossRef]

11. Pan, H.; Zhuang, M.; Geng, Y.; Wu, F.; Dong, H. Emergy-based ecological footprint analysis for a mega-city: The dynamic changes of Shanghai. J. Clean. Prod. 2019, 210, 552-562. [CrossRef]

12. Niccolucci, V.; Bastianoni, S.; Tiezzi, E.B.P.; Wackernagel, M.; Marchettini, N. How deep is the footprint? A 3D representation. Ecol. Model. 2009, 220, 2819-2823. [CrossRef]

13. Niccolucci, V.; Galli, A.; Reed, A.; Neri, E.; Wackernagel, M.; Bastianoni, S. Towards a 3D National Ecological Footprint Geography. Ecol. Model. 2011, 222, 2939-2944. [CrossRef]

14. Fang, K.; Reinout, H. A review on three-dimensional ecological footprint model for natural capital accounting. Prog. Geogr. 2012, 31, 1700-1707. [CrossRef]

15. Fang, K. Assessing the natural capital use of eleven nations: An application of a revised three-dimensional model of ecological footprint. Acta Ecol. Sin. 2015, 35, 3766-3777. [CrossRef]

16. Peng, J.; Du, Y.; Ma, J.; Liu, Z.; Liu, Y.; Wei, H. Sustainability evaluation of natural capital utilization based on 3DEF model: A case study in Beijing City, China. Ecol. Indic. 2015, 58, 254-266. [CrossRef]

17. Du, Y.; Peng, J.; Gao, Y.; Zhao, H. Sustainability evaluation of natural capital utilization based on a three-dimensional ecological footprint model: A case study of the Beijing-Tianjin-Hebei Metropolitan region. Prog. Geogr. 2016, 35, 1186-1196. [CrossRef]

18. Xun, F.; Hu, Y. Evaluation of ecological sustainability based on a revised three-dimensional ecological footprint model in Shandong Province, China. Sci. Total Environ. 2019, 649, 582-591. [CrossRef] 
19. Yang, Y.; Ling, S.; Zhang, T.; Yao, C. Three-dimensional ecological footprint assessment for ecologically sensitive areas: A case study of the Southern Qin Ling piedmont in Shaanxi, China. J. Clean. Prod. 2018, 194, 540-553. [CrossRef]

20. Yang, Y.; Hu, D. Natural capital utilization based on a three-dimensional ecological footprint model: A case study in northern Shaanxi, China. Ecol. Indic. 2018, 87, 178-188. [CrossRef]

21. Destek, M.A.; Sarkodie, S.A. Investigation of environmental Kuznets curve for ecological footprint: The role of energy and financial development. Sci. Total Environ. 2019, 650, 2483-2489. [CrossRef] [PubMed]

22. Wetzel, K.R.; Wetzel, J.F. Sizing the earth: Recognition of economic carrying capacity. Ecol. Econ. 1995, 12, 13-21. [CrossRef]

23. Waggoner, P.E.; Ausubel, J.H. A framework for sustainability science: A renovated IPAT identity. Proc. Natl. Acad. Sci. USA 2002, 99, 7860-7865. [CrossRef] [PubMed]

24. York, R.; Rosa, E.A.; Dietz, T. STIRPAT, IPAT and ImPACT: Analytic tools for unpacking the driving forces of environmental impacts. Ecol. Econ. 2003, 46, 351-365. [CrossRef]

25. Solarin, S.A.; Bello, M.O. Persistence of policy shocks to an environmental degradation index: The case of ecological footprint in 128 developed and developing countries. Ecol. Indic. 2018, 89, 35-44. [CrossRef]

26. Sun, J.W. Changes in energy consumption and energy intensity: A complete decomposition model. Energy Econ. 1998, 20, 85-100. [CrossRef]

27. Al-mulali, U. The investigation of environmental Kuznets curve hypothesis in the advanced economies: The role of energy prices. Renew. Sustain. Energy Rev. 2016, 54, 1622-1631. [CrossRef]

28. Zhang, X.; Zeng, H. Dynamic of three dimensional ecological footprint in the Pearl River Delta and its driving factors. Acta Sci. Circumstantiae 2017, 37, 771-778. [CrossRef]

29. Andersson, J.O.; Lindroth, M. Ecologically unsustainable trade. Ecol. Econ. 2001, 37, 113-122. [CrossRef]

30. Al-Mulali, U.; Weng-Wai, C.; Sheau-Ting, L.; Mohammed, A.H. Investigating the environmental Kuznets curve (EKC) hypothesis by utilizing the ecological footprint as an indicator of environmental degradation. Ecol. Indic. 2015, 48, 315-323. [CrossRef]

31. Uddin, G.A.; Salahuddin, M.; Alam, K.; Gow, J. Ecological footprint and real income: Panel data evidence from the 27 highest emitting countries. Ecol. Indic. 2017, 77, 166-175. [CrossRef]

32. Ulucak, R.; Bilgili, F. A reinvestigation of EKC model by ecological footprint measurement for high, middle and low income countries. J. Clean. Prod. 2018, 188, 144-157. [CrossRef]

33. Jia, J.; Deng, H.; Duan, J.; Zhao, J. Analysis of the major drivers of the ecological footprint using the STIRPAT model and the PLS method-A case study in Henan Province, China. Ecol. Econ. 2009, 68, 2818-2824. [CrossRef]

34. McDonald, G.W.; Patterson, M.G. Ecological Footprints and interdependencies of New Zealand regions. Ecol. Econ. 2004, 50, 49-67. [CrossRef]

35. Chankrajang, T.; Muttarak, R. Green Returns to Education: Does Schooling Contribute to Pro-Environmental Behaviours? Evidence from Thailand. Ecol. Econ. 2017, 131, 434-448. [CrossRef]

36. Charfeddine, L.; Mrabet, Z. The impact of economic development and social-political factors on ecological footprint: A panel data analysis for 15 MENA countries. Renew. Sustain. Energy Rev. 2017, 76, 138-154. [CrossRef]

37. Wang, Y.; Jiang, Y.; Zheng, Y.; Wang, H. Assessing the ecological carrying capacity based on revised three-dimensional ecological footprint model in Inner Mongolia, China. Sustainability 2019, 11, 2002. [CrossRef]

38. Alola, A.A.; Bekun, F.V.; Sarkodie, S.A. Dynamic impact of trade policy, economic growth, fertility rate, renewable and non-renewable energy consumption on ecological footprint in Europe. Sci. Total Environ. 2019, 685, 702-709. [CrossRef]

39. Pickett, S.T.A.; Cadenasso, M.L.; Childers, D.L.; Mcdonnell, M.J.; Zhou, W. Evolution and future of urban ecological science: Ecology in, of, and for the city. Ecosyst. Health Sustain. 2016, 2, e01229. [CrossRef]

40. Steffen, W.; Richardson, K.; Rockström, J.; Cornell, S.E.; Fetzer, I.; Bennett, E.M.; Biggs, R.; Carpenter, S.R.; De Vries, W.; De Wit, C.A.; et al. Planetary boundaries: Guiding human development on a changing planet. Science 2015, 347, 1259855. [CrossRef]

41. Haberl, H.; Erb, K.H.; Krausmann, F. How to calculate and interpret ecological footprints for long periods of time: The case of Austria 1926-1995. Ecol. Econ. 2001, 38, 25-45. [CrossRef] 
42. Krausmann, F.; Erb, K.H.; Gingrich, S.; Lauk, C.; Haberl, H. Global patterns of socioeconomic biomass flows in the year 2000: A comprehensive assessment of supply, consumption and constraints. Ecol. Econ. 2008, 65, 471-487. [CrossRef]

43. Borucke, M.; Galli, A.; Iha, K.; Mattoon, S.; Morales, J.; Poblete, P.; Wackernagal, M. The National Footprint Accounts, 2012 Edition; Global Footprint Network: Oakland, CA, USA, 2012.

44. Gong, P.; Liu, H.; Zhang, M.; Li, C.; Wang, J.; Huang, H.; Clinton, N.; Ji, L.; Li, W.; Bai, Y.; et al. Stable classification with limited sample: Transferring a 30-m resolution sample set collected in 2015 to mapping 10-m resolution global land cover in 2017. Sci. Bull. 2019, 64, 370-373. [CrossRef]

45. Lu, Y.; Zhang, Y.; Cao, X.; Wang, C.; Wang, Y.; Zhang, M.; Ferrier, R.C.; Jenkins, A.; Yuan, J.; Bailey, M.J.; et al. Forty years of reform and opening up: China's progress toward a sustainable path. Sci. Adv. 2019, 5, eaau9413. [CrossRef] [PubMed]

46. Ma, M.; Ma, X.; Xie, Y.; Ma, T. Analysis the relationship between ecological footprint (EF) of ningxia and influencing factors: Partial Least-Squares Regression. Acta Ecol. Sin. 2014, 34, 682-689. [CrossRef]

47. Costanza, R.; D'Arge, R.; De Groot, R.; Farber, S.; Grasso, M.; Hannon, B.; Limburg, K.; Naeem, S.; O’Neill, R.V.; Paruelo, J.; et al. The value of the world's ecosystem services and natural capital. Nature 1997, 387, $253-260$. [CrossRef]

48. Spellerberg, I.F.; Fedor, P.J. A tribute to Claude-Shannon (1916-2001) and a plea for more rigorous use of species richness, species diversity and the "Shannon-Wiener" Index. Glob. Ecol. Biogeogr. 2003, 12, 177-179. [CrossRef]

49. Chertow, M.R. The IPAT Equation and Its Variants. J. Ind. Ecol. 2000, 76, 138-154. [CrossRef]

50. Harrigan, K.R.; Guardo, M.C.D.; Bo, C. Multiplicative-innovation synergies: Tests in technological acquisitions. J. Technol. Transf. 2017, 42, 1212-1233. [CrossRef]

51. Wang, H.; Wu, Z.; Meng, J. Partial Lease-Squares Regression-Linear and Nonlinear Methods; National Defense Industry Press: Beijing, China, 2006.

52. Wold, S.; Kettaneh, N.; Tjessem, K. Hierarchical multiblock PLS and PC models for easier model interpretation and as an alternative to variable selection. J. Chemom. 1996, 10, 463-482. [CrossRef]

53. Moore, D.; Tam, L.; Tway, T.; Iha, K.; Thompson, P. Ecological Footprint analysis San Francisco-Oakland-Fremont, CA; Global Footprint Network: Oakland, CA, USA, 2011.

54. Wackernagel, M.; Schulz, N.B.; Deumling, D.; Linares, A.C.; Jenkins, M.; Kapos, V.; Monfreda, C.; Loh, J.; Myers, N.; Norgaard, R.; et al. Tracking the ecological overshoot of the human economy. Proc. Natl. Acad. Sci. USA 2002, 99, 9266-9271. [CrossRef] [PubMed]

55. Warren-Rhodes, K.; Koenig, A. Ecosystem appropriation by Hong Kong and its implications for sustainable development. Ecol. Econ. 2001, 39, 347-359. [CrossRef]

56. Musetta-Lambert, J.L.; Enanga, E.M.; Teichert, S.; Creed, I.F.; Kidd, K.A.; Kreutzweiser, D.P.; Sibley, P.K. Industrial innovation and infrastructure as drivers of change in the Canadian boreal zone1. Environ. Rev. 2019, 27, 275-294. [CrossRef]

57. Federici, M.; Ulgiati, S.; Verdesca, D.; Basosi, R. Efficiency and sustainability indicators for passenger and commodities transportation systems. The case of Siena, Italy. Ecol. Indic. 2003, 3, 155-169. [CrossRef]

58. Hu, J.; Wood, R.; Tukker, A.; Boonman, H.; de Boer, B. Global transport emissions in the Swedish carbon footprint. J. Clean. Prod. 2019, 226, 210-220. [CrossRef]

59. Berg, H.; Michélsen, P.; Troell, M.; Folke, C.; Kautsky, N. Managing aquaculture for sustainability in tropical Lake Kariba, Zimbabwe. Ecol. Econ. 1996, 18, 141-159. [CrossRef]

60. Gyllenhammar, A.; Håkanson, L. Environmental consequence analyses of fish farm emissions related to different scales and exemplified by data from the Baltic-A review. Mar. Environ. Res. 2005, 60, 211-243. [CrossRef]

61. Gerbens-Leenes, P.W.; Nonhebel, S. Consumption patterns and their effects on land required for food. Ecol. Econ. 2002, 42, 185-199. [CrossRef]

62. Zhao, J.; Liu, X.; Dong, R.; Shao, G. Landsenses ecology and ecological planning toward sustainable development. Int. J. Sustain. Dev. World Ecol. 2015, 23, 293-297. [CrossRef]

63. Al-mulali, U.; Solarin, S. Investigating the environmental Kuznets curve hypothesis in seven regions: The role of renewable energy. Ecol. Indic. 2016, 67, 267-282. [CrossRef] 
64. Hafeez, M.; Yuan, C.; Shahzad, K.; Aziz, B.; Iqbal, K.; Raza, S. An empirical evaluation of financial development-carbon footprint nexus in One Belt and Road region. Environ. Sci. Pollut. Res. 2019, 26, 25026-25036. [CrossRef] [PubMed]

65. Sadorsky, P. The impact of financial development on energy consumption in emerging economies. Energy Policy 2010, 38, 2528-2535. [CrossRef]

66. Santos-Martín, F.; Zorrilla-Miras, P.; García-Llorente, M.; Quintas-Soriano, C.; Montes, C.; Benayas, J.; Gómez Sal, A.; Paracchini, M.L. Identifying win-win situations in agricultural landscapes: An integrated ecosystem services assessment for Spain. Landsc. Ecol. 2019, 34, 1789-1805. [CrossRef]

67. Wu, Y.; Tian, X.; Li, X.; Yuan, H.; Liu, G. Characteristics, influencing factors, and environmental effects of plate waste at university canteens in Beijing, China. Resour. Conserv. Recycl. 2019, 149, 151-159. [CrossRef]

68. Bratman, G.N.; Anderson, C.B.; Berman, M.G.; Cochran, B.; de Vries, S.; Flanders, J.; Folke, C.; Frumkin, H.; Gross, J.J.; Hartig, T.; et al. Nature and mental health: An ecosystem service perspective. Sci. Adv. 2019, 5, eaax0903. [CrossRef] [PubMed]

69. Chojnacka, K.; Kowalski, Z.; Kulczycka, J.; Dmytryk, A.; Górecki, H.; Ligas, B.; Gramza, M. Carbon footprint of fertilizer technologies. J. Environ. Manag. 2019, 231, 962-967. [CrossRef] [PubMed]

70. Zhang, L.; Dzakpasu, M.; Chen, R.; Wang, X.C.C. Validity and utility of ecological footprint accounting: A state-of-the-art review. Sustain. Cities Soc. 2017, 32, 411-416. [CrossRef]

71. Ress, W.; Wackernagel, M. Urban Ecological Footprints: Why Cities Cannot be Sustainable-And Why They are a Key to Sustainability. Environ. Impact Assess. Rev. 2008, 16, 537-555. [CrossRef]

72. Pickett, S.T.A.; Cadenasso, M.L.; Grove, J.M. Resilient cities: Meaning, models, and metaphor for integrating the ecological, socio-economic, and planning realms. Landsc. Urban. Plan. 2004, 69, 369-384. [CrossRef]

73. Seelan, S.K.; Laguette, S.; Casady, G.M.; George, A.S. Remote sensing applications for precision agriculture: A learning community approach. Remote Sens. Environ. 2003, 88, 157-169. [CrossRef]

74. Linares, N.; Silvestre-Albero, A.M.; Serrano, E.; Silvestre-Albero, J.; García-Martínez, J. Mesoporous materials for clean energy technologies. Chem. Soc. Rev. 2014, 43, 7681-7717. [CrossRef] [PubMed]

75. Zhou, X.; Imura, H. How does consumer behavior influence regional ecological footprints? An empirical analysis for Chinese regions based on the multi-region input-output model. Ecol. Econ. 2011, 71, 171-179. [CrossRef]

76. Stern, D.I. The rise and fall of the Environmental Kuznets. Curve. World Dev. 2004, 32, 1419-1439. [CrossRef]

77. Verhofstadt, E.; Ootegem, L.V.; Defloor, B.; Bleys, B. Linking individuals' ecological footprint to their subjective well-being. Ecol. Econ. 2016, 127, 80-89. [CrossRef]

78. Galli, A.; Iha, K.; Pires, S.M.; Mancini, M.S.; Alves, A.; Zokai, G.; Lin, D.; Murthy, A.; Wackernagel, M. Assessing the ecological footprint and biocapacity of Portuguese cities: Critical results for environmental awareness and local management. Cities 2020, 96, 102442. [CrossRef]

Publisher's Note: MDPI stays neutral with regard to jurisdictional claims in published maps and institutional affiliations.

(C) 2020 by the authors. Licensee MDPI, Basel, Switzerland. This article is an open access article distributed under the terms and conditions of the Creative Commons Attribution (CC BY) license (http://creativecommons.org/licenses/by/4.0/). 